\title{
COMPARATIVE LINGUISTICS OF MESOAMERICAN LANGUAGES TODAY
}

\author{
LINGÜÍSTICA COMPARADA \\ DE LAS LENGUAS DE MESOAMÉRICA HOY
}

\author{
Lyle Campbell \\ University of Hawaìi Mānoa \\ lylecamp@hawaii.edu
}

DOI: $10.1387 /$ veleia.16827

\begin{abstract}
This chapter examines the current state of comparative linguistics applied to the ten language families and isolates of Mesoamerica. The classification of the Mesoamerican languages is well established and the reconstruction of the proto-languages is advanced. Proposals of distant genetic relationship involving languages of Mesoamerica are evaluated. Remaining tasks and some issues are identified and discussed together with recommendations for future research.

Keywords: Mesoamerican languages, comparative method, language classification, sound change, distant genetic relationships.

Resumen: Este artículo examina el estado actual de la Lingüística Comparada aplicada a las diez familias lingüísticas y lenguas aisladas de Mesoamérica. La clasificación de las lenguas mesoamericanas está bien establecida y también está avanzada la reconstrucción de las protolenguas. Se evalúan algunas propuestas de relación genética distante que implican a lenguas de Mesoamérica. Se establecen y discuten las tareas pendientes, junto con las recomendaciones para futuras investigaciones.

Palabras clave: Lenguas mesoamericanas, Método Comparativo, clasificación de lenguas, cambio fonético, relaciones genéticas distantes.
\end{abstract}

Recibido: 07-09-2015

Informado: 29-04-2016

Definitivo: 02-05-2016

\section{Introduction}

The goal of this chapter is to report on the current state of the comparative linguistics of Mesoamerican language families and to make some recommendations for future research. The classification of the Mesoamerican languages is well established and the reconstruction of the respective proto-languages is advanced. In general, the historical linguistic research on Mesoamerican languages has been of high quality, though naturally further advances are possible, and not all historical linguistic works written about these languages have been of value to the field. 
Mesoamerica is home to about 140 languages, classified into ten language families (including three language isolates). The term "Mesoamerica" refers to a culture area defined by a number of cultural traits shared by the pre-Columbian cultures of the geographical region that extends from the Pánuco River in northern Mexico to the Lempa River in El Salvador, continuing along the Pacific coast of Nicaragua and Costa Rica. Mesoamerica is also a linguistic area, which coincides approximately with the territory of the Mesoamerican culture area, defined by shared linguistic traits among languages of the area (cf. Campbell, Kaufman, and Smith-Stark 1986) ${ }^{1}$.

This paper reports the classifications of these languages and discusses aspects of the reconstruction of the respective proto-languages. The consensus classification and reconstructions presented here represents the culmination of investigations that extend over two centuries, and some highlights in this history are mentioned in connection with some of the families. The tasks that remain to be done in order to improve the subgrouping classification of these families and to reach more complete reconstructions are considered. Finally, hypotheses of distant genetic relationships which involve these languages are assessed ${ }^{2}$.

\section{Classification}

There is general agreement that Mesoamerica has seven established and mostly uncontroversial language families - Mayan, Mixe-Zoquean, Tequistlatecan, Totonacan (Totonac-Tepehua), Otomanguean, Uto-Aztecan, and Xinkan - and three language isolates - Cuitlatec, Huave, and Tarascan (Purépecha) ${ }^{3}$. In what follows, the subgrouping classification of these language families is presented, based on the criterion of shared innovations (the only reliable evidence of closer relationship; cf. Campbell 2013, 175-184), and a few examples involving their reconstruction are given. The subgrouping relationships are indicated by the degree of indentation in the list of branches and language names. Language group headings more to the left include as their members all the groups and languages under them that are more indented towards the right. Greater degree of indentation thus reflects hierarchically the degrees of relatedness in family trees.

\subsection{Mayan}

Languages of the Mayan family are spoken in Guatemala, southern Mexico, Belize, and a small area in Honduras. The most widely accepted classification of the languages of the family is:

\footnotetext{
1 Sometimes "Mesoamerica" is confused with "Middle America," the region covering all of Mexico and Central America. This paper deals only with languages of Mesoamerica proper, though with occasional mention of language neighboring Mesoamerica.

2 There are, of course, numerous other themes in Mesoamerican historical linguistics of significant interest; for example, language contact and areal linguistics is a big one (see Campbell et al. 1986, Law 2015). How-
}

ever, due to space limitations, his paper concentrates only on comparative linguistics and reconstruction, the theme of the volume.

3 Garífuna (formerly called Black Carib, an Arawakan language, whose relatives are in South America) is a late arrival to Central America from the Caribbean. It does not share the linguistic traits of other Mesoamerican languages and is not discussed further here. 


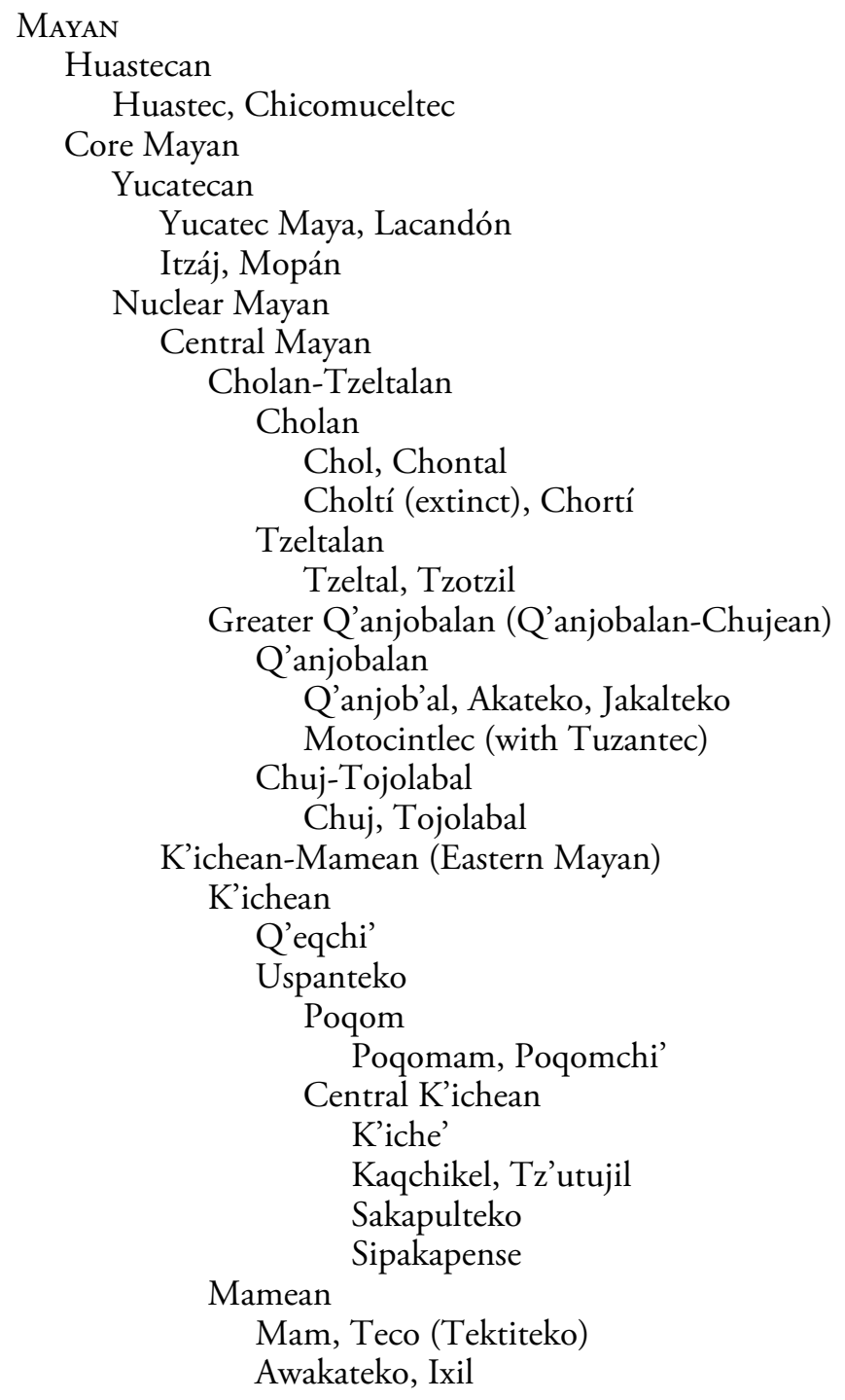

(Campbell in press, Campbell and Kaufman 1985).

Relationships among Mayan languages have been recognized since early colonial times. Several scholars of Mayan comparative linguistics utilized methods developed in the study of Indo-European languages at almost the same time that these methods were being developed. For example, Charles Felix Hyacinthe, Le Comte de Charencey [1832-1916] (1870) used sound correspondences to classify and subgroup the languages of Mesoamerica. Charencey's 1872 and 1883 papers include several Mayan sound correspondences and sound changes. Otto Stoll [1849-1922] (1885) also presented a number of sound correspondences and associated sound changes among Mayan languages, saying:

"These changes follow regular phonetic laws and bear a strong affinity to the principle of "Lautverschiebung" (Grimm's law), long ago known as an agent of most extensive application in the morphology of the Indo-Germanic languages.” [Emphasis added, LC.] (Stoll 1885, 257). 
Stoll (1912-1913, 40) expounded further:

"When ... it concerns ... on which basis ... I proposed the diversification of the Mayan family ... the following can here be mentioned ... One of the most striking difference between the individual groups of Mayan languages is the regular sound shift from one group to the other [several examples of which are given $]^{4 ”}$.

Serious comparative syntactic study of Mayan languages was undertaken by Eduard Seler [1849-1922], the most renowned authority on Mesoamerican antiquities in his day, but trained in comparative linguistics. His dissertation on the historical morphology and syntax of Mayan languages at the University of Leipzig, Das Konjugationssystem der Maya-Sprachen (Seler 1887), was in the Indo-Europeanist mode of the time, but actually appeared before Delbrück's celebrated work on comparative Indo-European syntax (Delbrück 1888, 1893), which is held by many to be the foundation of historical syntax in the Neogrammarian tradition.

Abraham M. Halpern (1942) presented the first real reconstruction of several ProtoMayan sounds, based on a set of sound correspondences. Norman McQuown (1955, 1956) is often credited as founder of modern Mayan comparative linguistics. Several Proto-Mayan phonemes which McQuown postulated were eliminated in later refinements (see Kaufman 1964, 1969, Kaufman and Norman 1984, Kaufman with Justeson 2003, and Campbell 1977, 89-90, 97-101, 1988, 6-12, in press). The classification and the picture of Proto-Mayan reconstruction given in Campbell and Kaufman (1985) still represents the consensus view, for the most part.

It is clear that the Huastecan branch was the first to separate from the rest of the family. Next, Yucatecan branched off, and then later the remaining Core Mayan separated into distinct branches. The subgroups (subfamilies) Huastecan, Yucatecan, Ch'olan-Tzeltalan, Greater Q'anjob'alan, and Eastern Mayan (Mamean-K'ichean) are clear and for the most part uncontroversial. It is generally believed that Ch'olan-Tzeltalan and Greater Q'anjob'alan belong together in a single higher order branch, though the evidence for this is not entirely certain. Opinions have differed about whether Tojolabal belongs to Greater Q'anjob'alan or to Ch'olan-Tzeltalan (see Law 2014 for a survey of opinions).

Several Mayan languages have extensive attestations beginning shortly after earliest Spanish contact, written in the indigenous languages using Spanish orthography. These include dictionaries and grammars, as well as abundant religious texts, land claims, native histories, etc. Mayan hieroglyphic writing provides very early attestations reflecting Cholan, and later also Yucatecan.

The inventory of reconstructed Proto-Mayan phonemes is seen in Chart 1 (see Campbell in press).

\footnotetext{
4 Wenn es sich ... darum handelt ... auf deren Grund ich ... die Zerfällung der Maya-Sprachfamilie ... so kann hier ... folgendes erwähnt werden: ... Einer augenfälligsten Unterschiede zwischen den einzelnen Gruppen der
}

Maya-Sprachen ist die gesetzmässige Lautverschiebung von einer Gruppe zur andern. [Emphasis mine, LC.] (Stoll 1912-13, 40). 


\begin{tabular}{|c|c|c|c|c|c|c|c|}
\hline $\mathrm{p}$ & $t$ & $t$ & ts & č & $\mathrm{k}$ & $q$ & ? \\
\hline \multirow[t]{2}{*}{$\mathrm{f}$} & $\begin{array}{l}\mathrm{t}^{\prime} \\
1\end{array}$ & $t^{\prime}$ & ts' & $\check{c}^{\prime}$ & $\mathrm{k}^{\prime}$ & q' & \\
\hline & $\mathrm{r}$ & & & & & & \\
\hline \multirow[t]{2}{*}{$\mathrm{m}$} & $\mathrm{n}$ & & & & $\eta$ & & \\
\hline & s & & & $\check{s}$ & & $\chi$ & \\
\hline \multirow[t]{3}{*}{$\mathrm{w}$} & & & & $\mathrm{y}$ & & & h \\
\hline & i & $\mathrm{e}$ & $\mathrm{a}$ & o & $\mathrm{u}$ & & \\
\hline & & 11 & & & & & \\
\hline
\end{tabular}

Chart i. Proto-Mayan phonemes

Campbell (in press) presents arguments for replacing the conventionally reconstructed velar ${ }^{*} x$ with uvular ${ }^{*} \chi,{ }^{*} t$ with ${ }^{*} t$ (also ${ }^{*} t^{\prime}$ with $\left.{ }^{*} t^{\prime}\right)$, and ${ }^{*} t^{\mathrm{y}}$ with ${ }^{*} t$ (also ${ }^{*} t^{\mathrm{y}}$ with $\left.{ }^{*} t^{\prime}\right)$.

The following few examples give an idea of the reconstructions, sound changes, and in particular, the shared innovations that help define some of the subgroups. Languages of the Mamean subfamily share:

$$
\begin{aligned}
& \text { Proto-Mayan * } \mathrm{r}>\mathrm{t} \\
& \text { Proto-Mayan *t }>\text { č; * } \mathrm{t}^{\prime}>\mathrm{c}^{\prime}
\end{aligned}
$$

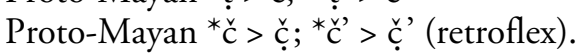

Languages of the K'ichean-Mamean (Eastern Mayan) subgroup share:

$$
\begin{aligned}
& \text { Proto-Mayan }{ }^{*} y>x . \\
& \text { Proto-Mayan }{ }^{*} t>\text { affricate ( } t s \text { in Mamean, } c ̌ \text { in K'ichean). }
\end{aligned}
$$

Proto-Mayan morphosyntax and the grammatical changes in the various languages are not well known; nevertheless, the study of Mayan historical syntax is considerably in advance of that of most other language families in the Americas and of most other language families, too, for that matter. These studies include, for example, England (1991) on word order, Kaufman and Norman (1984) with Ch'olan morphology, Mora-Marín (2003) on reconstruction of applicative and antidative constructions, Norman (1978) on "instrumental voice," Norman and Campbell (1978) about Proto-Mayan syntax generally, Robertson (1992) on tense/aspect/mood/voice in verbs, and especially Kaufman's (2002) detailed treatment of Mayan morphosyntax. These studies reveal that Proto-Mayan was an ergative language, with associated antipassive constructions. The subjects of intransitive verbs and the objects of transitive verbs were marked in the same way, both bearing absolutive cross-referencing markers, distinct from the marking of subjects of transitive verbs, which bore ergative markers. It is argued that Proto-Mayan had VOS (Verb-Object-Subject) basic word order when the subject was higher than the object on the "animacy" hierarchy (where 'human' is highest, 'animate' next highest, and 'inanimate' lowest), but had VSO word order when subject and object were equal in animacy. (See Kaufman 2002). 
2.2. Mixe-Zoquean

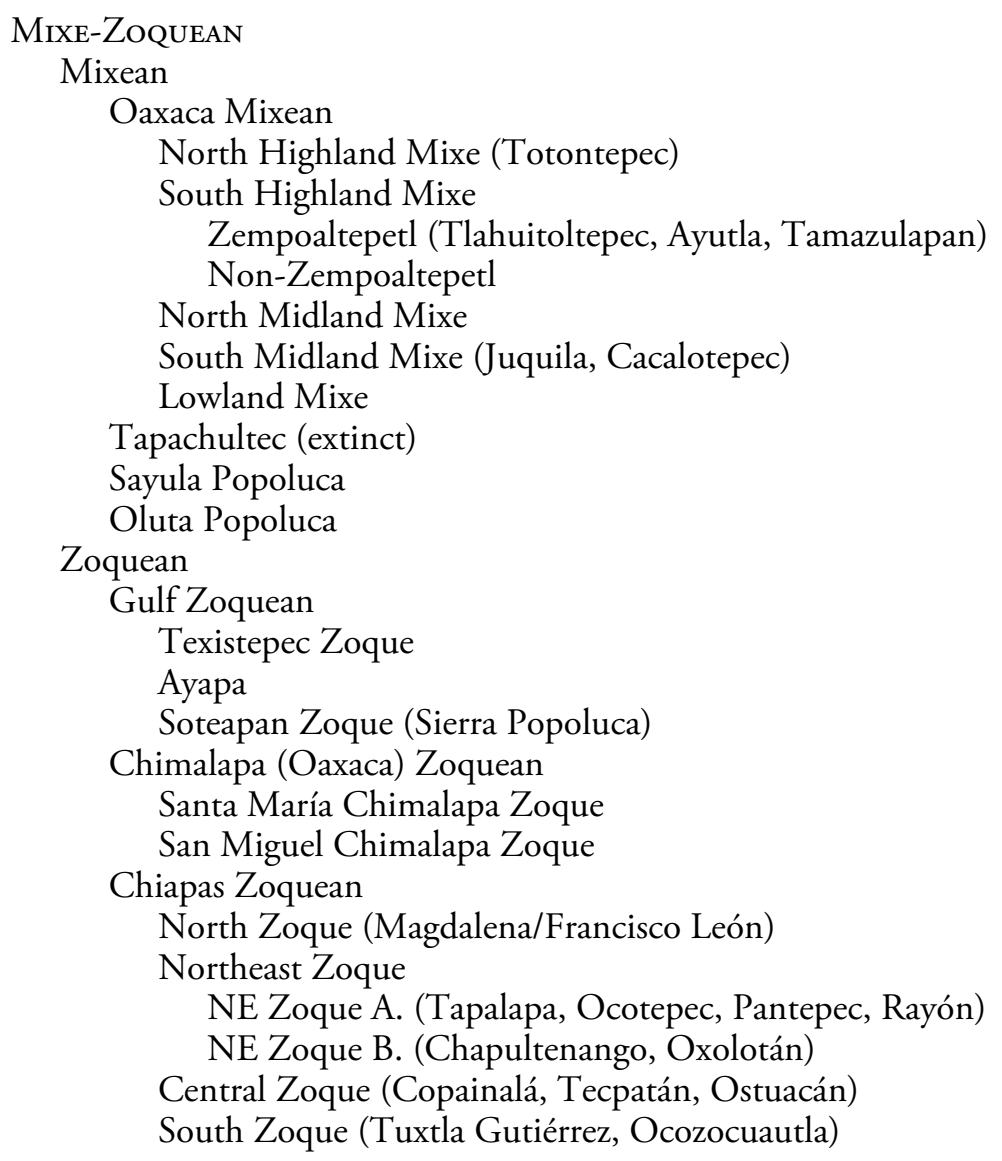

(See Wichman 1995, Justeson and Kaufman 1993, 1704).

Proto-Mixe-Zoquean had the following phonemes: /p, t, ts, k, ?, s, m, n, w, y, h; i, e, a, i, o, $\mathrm{u} /$. The Olmec civilization appears to have been borne, at least in part, by speakers of Mixe-Zoquean (Campbell and Kaufman 1976). The Epi-Olmec writing system represents an early form of Zoquean (Justeson and Kaufman 1993, Kaufman and Justeson 2008).

\title{
2.3. Otomanguean
}

\author{
OTOMANGUEAN \\ Western Otomanguean \\ Oto-Pame-Chinantecan \\ Oto-pamean \\ Southern Oto-pamean \\ Otomí-Mazahua \\ Otomí \\ Northeastern Otomí \\ Northwestern Otomí \\ Western Otomí
}




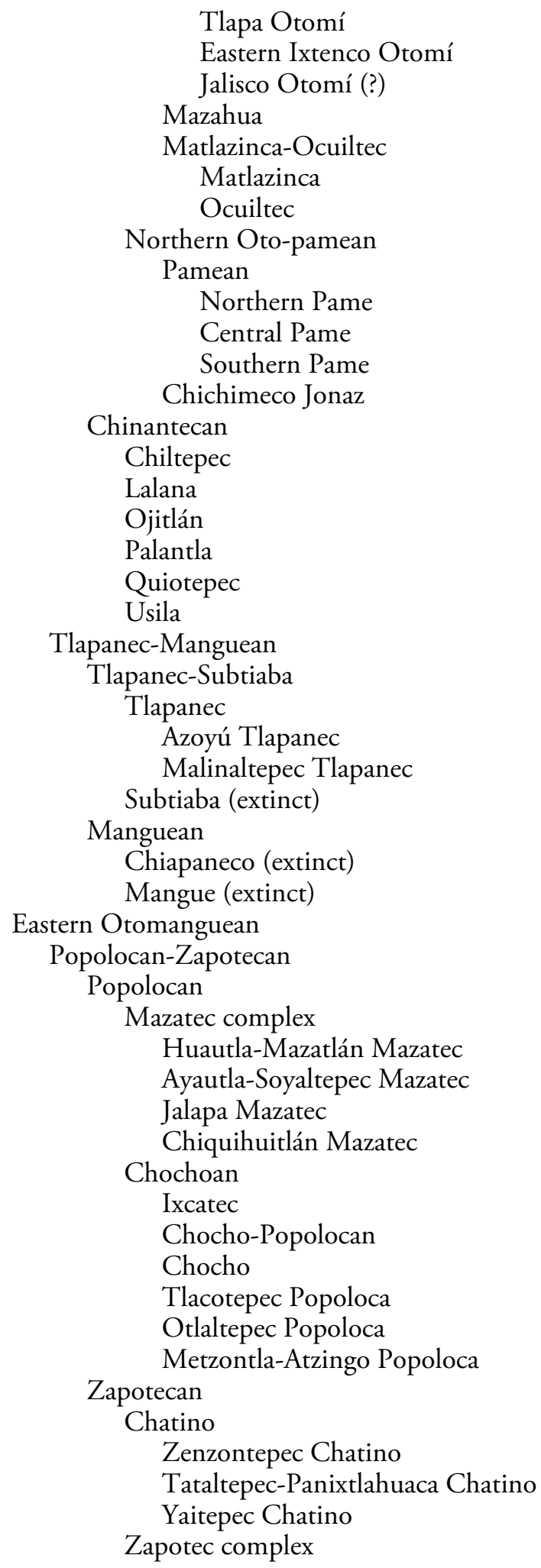




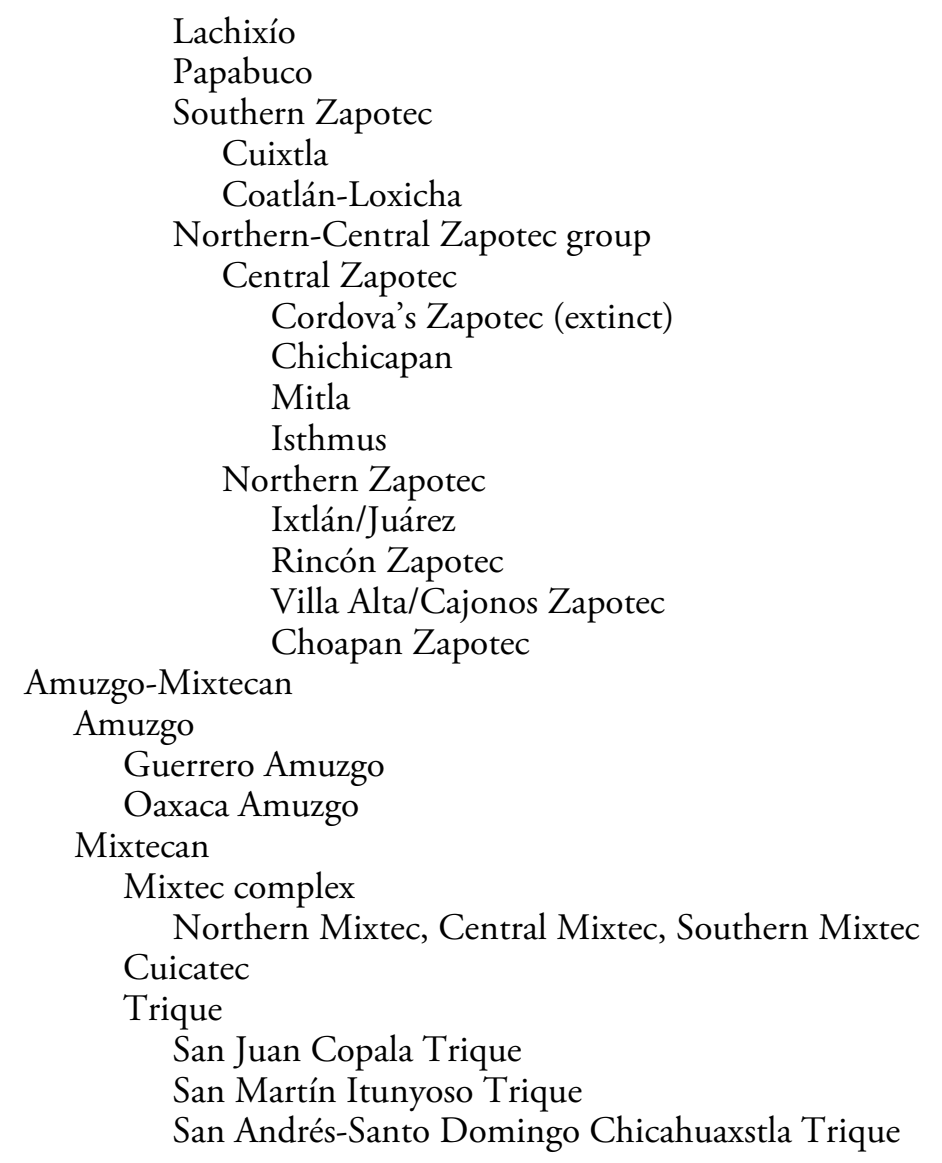

(See Campbell 1997, Kaufman 2006).

Relationships among Otomanguean languages were discovered over time. For example, Hervás y Panduro (1800-1805) correctly recognized the relationship among Otomí, Mazahua, and Chichimec. By the late 1960s the relatedness of most of the Otomanguean languages to one another had been established (see Rensch 1976), and finally Tlapanec-Subtiaba was definitively demonstrated to belong to Otomanguean (Rensch 1977, Suárez 1986). Previously Tlapanec and Subtiaba had generally been considered to be part of the large but now mostly abandoned Hokan hypothesis (Sapir 1925). General agreement on the precise number of languages in the Zapotec Complex and the Mixtec Complex has been difficult to reach (see the Catalogue of Endangered Languages, at www.endangeredlanguages.com, for the most accurate classification of the languages in the Zapotec and Mixtec complexes).

Some Otomangueanists believe that Otomanguean reconstruction is so advanced as to rival that of Indo-European (see, for example, Longacre 1968, 333), though this view is not widely shared.

\subsection{Uto-Aztecan}

Uto-Aztecan languages extend from Oregon to Costa Rica. Only the Aztecan (Nahuan) branch is located squarely inside of Mesoamerica. Cora and Huichol were influenced by Mesoameri- 
can languages and have some Mesoamerican traits. The other Uto-Aztecan languages lie outside Mesoamerica, though the members of the Southern Uto-Aztecan branch are mostly in northern Mexico.

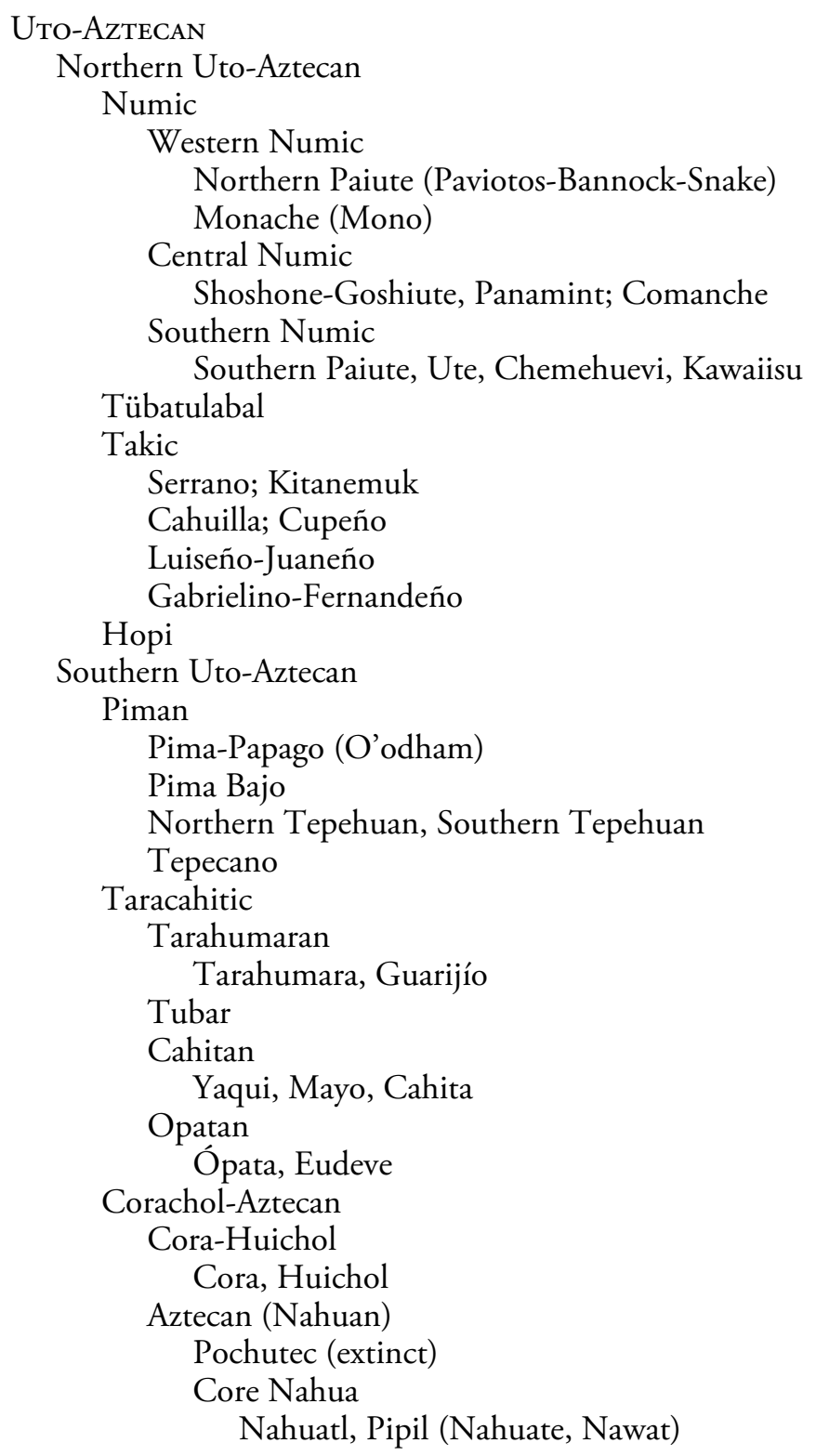

(Cf. Campbell 1997, 134-138).

In addition to these languages, there is a long list of names identified in colonial sources which are generally thought to represent extinct Uto-Aztecan languages. No information has survived on most of these and it is not certain whether they represent independent languages or just alternative names of languages already known by another name (see Harvey 1972, Sauer 1934, Campbell 1997, 133-135). 
Daniel G. Brinton coined the name Uto-Aztecan and combined the three branches, Aztecan, Sonoran, and Shoshonean, in this family (cf. Brinton 1891). John Wesley Powell (1966 [1891], 216) had rejected this classification in his extremely influential classification of North American languages, but it was later fully confirmed by Edward Sapir (1913-1919 [1915]) in his important work that demonstrated that the comparative method and the regularity of sound change also hold for unwritten, "exotic" languages, not just for languages similar to Indo-European, as some had thought.

The reconstructed phonemes of Proto-Uto-Aztecan are: /p, t, ts, k, kw, P, s, h, m, n, y, w, y, i, a, $\dot{\mathrm{i}}, \mathrm{o}, \mathrm{u} /$, with contrastive vowel length.

There is general agreement on the eight major branches of Uto-Aztecan: Numic, Takic, Tubatulabal, Hopi, Piman, Taracahitic, Cora-Huichol, and Aztecan (Nahua). The higher order Southern Uto-Aztecan branch is well-established, though not all scholars have embraced it, and some doubt whether the northern languages can be united into the single Northern Uto-Aztecan branch, though there is supportive evidence. The evidence for grouping Cora-Huichol and Aztecan (Nahua) together in a single subgroup is compelling (see Campbell and Langacker 1978), though some scholars continue to list them as separate branches in the family. Proto-Cora-Huichol and Proto-Aztecan share among others the innovations from Proto-Uto-Aztecan:

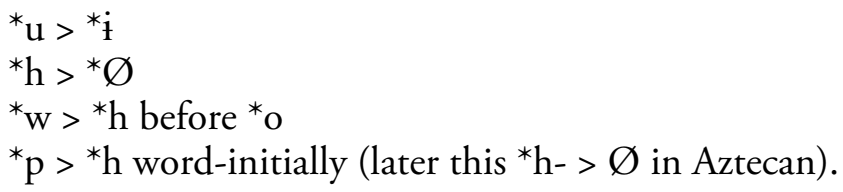

This is conclusive evidence that Cora-Huichol and Aztecan belong together as a subgroup.

Most Uto-Aztecanists hold that the Proto-Uto-Aztecan speakers were hunter-gatherers whose homeland was in the Southwestern US-northeastern Mexico border area. Jane Hill in several publications (see for example 2001, 2002) argues instead that Proto-Uto-Aztecans were maize cultivators, with their homeland in the south, associated with Mesoamerican maize agriculture -a view influenced by the farming/language dispersal hypothesis that sees agriculture as the driving force behind the dispersal of most language families (Bellwood 1997, Renfrew 1994, 2000; see Campbell and Poser 2008, 337-350 for a critique). There are serious problems with Hill's interpretation.

Most reconstructed Proto-Uto-Aztecan plant and animal terms are consistent with either a southern or the traditional northern homeland hypothesis; however, the center of gravity model of linguistic diversification (also called linguistic migration theory), based on minimum moves and maximum diversification, supports the traditional northern homeland. A southern homeland view has difficulty explaining the distribution of the languages, with less diversification in the south and more in the north. Similarly, Aztecan (Nahua), the only branch of Uto-Aztecan situated squarely in Mesoamerica, shows every sign of late entry into Mesoamerica, after breaking away from its Uto-Aztecan relatives. Aztecan acquired several Mesoamerican structural traits and underwent changes which make it more like its Mesoamerican neighbors but that set it off from other UtoAztecan languages (e.g. shift to VSO word order, shift of postpositions to relational nouns, etc.) (cf. Campbell, Kaufman and Smith-Stark 1986). Also, Aztecan borrowed much vocabulary that matches the ecology and cultural traits diagnostic of the Mesoamerican culture area, but is not reflective of the drier areas to the north. These are not the earmarks of a language in its homeland whose sisters departed towards the north.

In Hill's view, most of the northern Uto-Aztecan languages except Hopi lost agriculture, with the result that the argument for Proto-Uto-Aztecan agriculture rests very heavily on evidence from 
Hopi alone. Hill's principal evidence depends on nine putative Uto-Aztecan cognate sets, where the assumed maize associations are limited primarily to Hopi and Southern Uto-Aztecan languages. These comparisons are problematic in several ways. Some of these words have been assumed to be borrowings; for others, the semantic differences among the forms compared are so wide as to cast doubt on them being cognates, and several involve exceptions to Uto-Aztecan sound correspondences. Most require an assumption of considerable semantic shift, and in particular, for most a shift from an earlier non-agricultural meaning to later expanded meanings with associations with maize is more plausible. (See Campbell and Poser 2008, 347-350 for more detail of the problems with these sets).

In short the evidence Hill presented is very limited, only nine lexical comparison sets, and all of these have difficulties which either challenge cognacy or disfavor the interpretation that the original sense involved agriculture. Hill's cases appear to be better interpreted as semantic shifts from plants whose original meaning had no agricultural content to later senses involving cultivation, and not vice versa.

\title{
2.5. Totonacan
}

\author{
TOTONACAN \\ Totonac branch \\ Misantla Totonac \\ Coatepec Totonac \\ Zapotitlán Totonac \\ Xicotepec Totonac \\ Papantla Totonac \\ Tepehua (with the varieties, sometimes considered separate languages: \\ Tlachichilco, Huehuetla, and Pisaflores)
}

(See MacKay and Trechsel 2014).

\subsection{Tequistlatecan (Chontal of Oaxaca)}

\author{
Tequistlatecan \\ Huamelultec (Lowland Chontal) \\ Highland Chontal \\ Tequistlatec proper
}

Tequistlatean has been reconstructed with the phonemes: /p, t, ts, k, P, b, d, g, f, tl', ts', k', 1 , s, h, l, m, n, w, y, W, N, i, e, a, o, u/. The sounds W and $\mathrm{N}$ are voiceless and can perhaps be analysed as clusters of $h w$ and $h n$, respectively, instead of as separate phonemes. (See Turner 1969, Waterhouse 1969, Campbell 1997, 160).

Tequistlatecan had formerly been associated with the controversial and now mostly abandoned Hokan hypothesis.

\subsection{Xinkan}

Xinkan is a small family of four languages formerly spoken in southeastern Guatemala. They are not especially closely related, differing from one another on the order of Germanic languages. 
Only one or two semi-speakers of Guazacapán and one of Jumaytepeque remain; the other two languages are extinct.

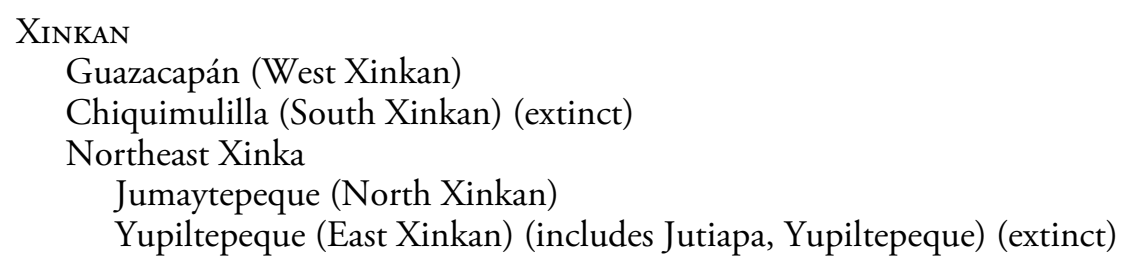

(See Rogers 2016).

The Proto-Xinkan phoneme inventory is seen in Chart 2.

\begin{tabular}{|c|c|c|c|c|c|c|}
\hline $\mathrm{p}$ & $\mathrm{t}$ & $\check{c}$ & $\mathrm{k}$ & ? & & \\
\hline \multirow[t]{2}{*}{ p' } & $\begin{array}{l}\mathrm{t}^{\prime} \\
\mathrm{ts}\end{array}$ & č' & $\mathrm{k}^{\prime}$ & & & \\
\hline & $s$ & ș & & $\mathrm{h}$ & & \\
\hline $\mathrm{m}$ & $\mathrm{n}$ & & & & & \\
\hline \multirow[t]{5}{*}{$\mathrm{m}^{\prime}$} & n' & & & & & \\
\hline & $\dashv$ & & & & & \\
\hline & $l^{\prime}$ & & & & & \\
\hline & $\mathrm{r}$ & & & & & \\
\hline & $\mathrm{r}^{\prime}$ & & & & & \\
\hline $\mathrm{w}$ & & $\mathrm{y}$ & & & & \\
\hline $\mathrm{w}^{\prime}$ & & $y^{\prime}$ & & & & \\
\hline $\mathrm{i}$ & $\dot{\mathrm{i}}$ & $\mathrm{u}$ & & i: & $\mathrm{i}:$ & $\mathrm{u}:$ \\
\hline \multirow{2}{*}{ e } & & o & & e: & & o: \\
\hline & $\mathrm{a}$ & & & & $\mathrm{a}:$ & \\
\hline
\end{tabular}

Chart 2. Proto-Xinkan phoneme inventory (Rogers 2016, 193)

Notably, Xinkan languages all have glottalized resonants as well as glottalized (ejective) stops and affricates, and a voiceless "l" (symbolized here as / $\mathbf{k} /$ ).

Xinkan with Lencan were often assumed to be related to one another, but the evidence does not support this, and the hypothesis has been abandoned (Campbell 1997, 325).

Xinkan provides an exception to the claims of the farming/language dispersal model (mentioned above). It sees farming dispersals, the expansion of populations of farmers, as responsible for the distribution of the languages of many of the world's language families, with farmers pushing out or assimilating their non-farming neighbors and their languages (Bellwood 1997, Renfrew 1994, 2000). However, nearly all Xinkan terms for cultigens are borrowed from Mayan languages (cf. Campbell 1972), showing that Xinkan speakers acquired agriculture from Mayan neighbors, but maintained their identity and language in face of the Mayan agriculturalists, not being swallowed up by their large agriculturalist neighbors as predicted by the model. 


\subsection{Tarascan (Purépecha)}

Though Tarascan is a language isolate, it has several different dialects. Paul Friedrich (1971) applied the comparative method to these dialects to arrive at a reconstruction of an earlier stage of Tarascan -a very valuable procedure for obtaining historical information about language isolates (applied also to Huave, see below).

There have been a few attempts, all unsuccessful, to demonstrate a linguistic kinship between Tarascan and other languages. For example, Swadesh (1966) proposed a relationship between Mayan and Tarascan, supposedly based on a number of proposed cognates, all flawed from the point of view of standard criteria for establishing genetic relationships among languages (see Campbell and Poser 2008; see Campbell 1997, 224-226 for evaluation of these data). Swadesh (1967) also proposed a Tarascan-Quechua connection, again based on very limited evidence exhibiting methodological flaws in the extreme (Campbell 1997, 325-326). Greenberg (1987, 106107 ) included Tarascan as a member of his putative Chibchan-Paezan phylum (a putative division of his grand "Amerind" macro-family) (see below), which also included other groups scattered from Florida to South America, e.g. Timucua, Cuitlatec, Lencan, Xinkan, and Warrau (Warao). Very little evidence was presented for the grouping and it has numerous methodological shortcomings (see Campbell 1997, 176).

\subsection{Cuitlatec}

Very little is known about the history of the language isolate Cuitlatec (see Heaton in press). There have been a number proposals attempting to link it to other language families. Walter Lehmann (1920) thought that Cuitlatec and Tlapanec belonged to a "Californian group," which he believed also contained a number of other languages, but he provided no significant evidence. Weitlaner (1939) considered possible similarities with Otomían languages. Lemley (1949) repeated the notion that Cuitlatec and Tlapanec might be related. Hendrichs Pérez (1947, 137-139) proposed that Cuitlatec might be related to Mayan. There is scarcely any evidence for any of these hypotheses.

The only real comparative work on Cuitlatec is by Arana Osnaya (1958). She attempted some reconstructions based on conventional kinds of evidence, with observations about possible sound changes, cautioning that the results were preliminary. She compared Cuitlatec lexicostatistically to several languages of the Americas; her results indicated that Cuitlatec is not closely related to any of the languages she considered, though she speculated that it might be related to Nahuatl and Paya at a time depth of 5,500 years based on 18 or 19 assumed cognates (really just lookalikes) from the 100-word list (Arana Osnaya 1958, 563). This result has generally not been considered reliable. (For a critique of these claims, see Heaton in press).

\subsection{Huave}

Huave is another language isolate, with four principal dialects, spoken in Oaxaca, Mexico. A number of proposals have tried to relate Huave to other languages, but none has proven wellfounded. They include proposed kinship with Mixe-Zoquean, Mexican Penutian, Otomanguean, Algonquian, 'Gulf languages, and Uralic. (See Campbell 1997 for evaluation of these unsupported proposals.)

Suárez (1975) applied internal reconstruction and the comparative method to the four main Huave dialects and reconstructed Proto-Huave. His reconstruction has a series of plain stops and 
pre-nasalized stops, contrastive vowel length (only in penultimate syllables), and tone. This application of the comparative method to the dialects, along with internal reconstruction, is another significant example, along with Friedrich's (1971) of Tarascan, of what can be done to increase understanding of the history of language isolates, important since it is often claimed that language isolates have no history (see Campbell 2011).

\section{TASKS FOR THE FUTURE}

The classification and basic phonological reconstruction of these language families are wellestablished, but much remains to be done to advance the historical linguistic study of these languages. These tasks include the following.

1. The reconstructed phonology and the sound changes that languages have undergone are generally well understood, especially in the larger families; nevertheless, refinements in phonological reconstruction are possible and are needed. As is well understood, the exact classification rests on and requires a valid reconstruction. The reconstruction of the phonology and a large part of the lexicon of the largest families, Proto-Mayan, Proto-Uto-Aztecan, Proto-Mixe-Zoquean, and Proto-Otomanguean, is in an advanced stage, but these can be refined (see Campbell in press for some proposed refinements involving Mayan). There are still some disagreements about some reconstructions involving some of these language families, and this invites us to try to harder to resolve them.

2. Etymological dictionaries are needed for the language families of Mesoamerica. Much information on the reconstructed vocabulary of Proto-Mayan (Kaufman with Justeson 2003), Proto-Mixe-Zoquean (Wichmann 1995), and Proto-Uto-Aztecan (Stubbs 2011) is available, but the need to prepare and publish more etymological dictionaries for these families is one of the most important tasks that confront us.

3. Another urgent task is to distinguish what is inherited in these languages from what is borrowing or due to language contact. For example, to address the problem of possible further genetic relationships it is necessary to separate what is inherited from what has entered the language by borrowing or areal diffusion. (See Law 2014).

4. The historical morphology and syntax of these languages must be investigated. We have scattered studies, for example those mentioned above involving Mayan languages, but they are few.

\section{Distant genetic Relationships?}

There are a considerable number of proposals of distant genetic relationships involving languages of Mesoamerica, though the evidence for most of these hypotheses is unconvincing (for critical evaluation of most, see Campbell 1997, 260-329). Nevertheless, it is possible that there may be as yet undiscovered genetic relationships which link some of language families and isolates with others in larger families which perhaps could be established if we set our minds to gathering and examining the evidence carefully, using appropriate methods. As seen above, numerous proposals attempt to group the language isolates of Mesoamerica with other languages. It seems that some take the existence of a language isolate, a language not classified as part of a larger family, as 
a challenge to try to establish a broader genetic affiliation for it. We need to examine the evidence for these hypotheses of distant genetic relationship - those involving isolates and those involving the other language families - carefully to eliminate the unsubstantiated ones and to encourage further research on any that prove promising.

\subsection{More promising hypotheses of remote linguistic relationship}

Nearly all of the proposals for remote kinship involving Mesoamerican languages are too weak to deserve much attention. Only two are promising.

Mayan-MixeZoquean. This hypothesis would join the Mayan and Mixe-Zoquean families into a single larger family. Some of the evidence that has been presented is less convincing (see, for example, Brown and Witkowski 1979), although the evidence and arguments presented by David Mora-Marín (2016) for this hypothesis are very encouraging. This case is made more difficult by the fact that after long centuries of mutual influence between these two neighboring families, it is sometimes not possible to distinguish between shared similarities that may be inherited (real cognates) and those that may be due to diffusion, borrowing.

Mora-Marín's (2016) recent investigation, utilizing careful methods, makes this proposal of genetic relatedness much more plausible. Attempts to find other remote relatives of Mayan will no doubt continue. It is impossible to anticipate how successful they may be, but it is unlikely that striking breakthroughs are in store, and proposals that do not follow careful, appropriate methods will certainly not hold up to scrutiny.

Tequistlatecan-Jicaquean. There is some suggestive evidence that the two small language families Tequistlatecan and Jicaquean (in Honduras) may be related. The case is sufficient to warrant more research, but the evidence that has been presented is very limited and the hypothesis is not as promising as the Mayan-MixeZoquean one (see Campbell 1979, 966-967, Campbell and Oltrogge 1980).

\subsection{Rejected proposals}

Most proposals for remote affinity involving Mesoamerican languages have been examined in detail, have not yielded positive results, and therefore have been rejected (see Campbell 1997, 260329). These include the following.

Macro-Mayan. Although Mayan-MixeZoquean merits further investigation, the broader MacroMayan hypothesis is doubtful. It includes Mayan, Mixe-Zoquean, Totonacan, and in some versions also Huave. The suggested connection with Huave is doubtful in the extreme. A possible Totonacan connection with either Mayan or Mixe-Zoquean is plausible, and proposals have favored both, although the evidence presented so far is unconvincing, violating standard methodological proocedures (see McQuown 1942, Brown et al. 2011; cf. Campbell 1997, 333-334).

Aztec-Tanoan. This proposes a relationship between the Kiowa-Tanoan and Uto-Aztecan families. Today it is thoroughly abandoned. See Campbell $(1997,269-273)$ for a detailed critique.

Mexican Penutian. To the now mostly abandoned Penutian hypothesis, which originally joined five language families of California, Sapir (1929) added a group he called "Mexican Penutian" which included Mixe-Zoquean and Huave, to which others later added Mayan, Totonacan, and Uto-Aztecan. No specialist today accepts any version of Mexican Penutian. (See Campbell 1997, 320). 
Maya-Chipaya(-Yunga). Olson $(1964,1965)$ published similarities arguing for a genetic relationship between Mayan and Chipaya-Uru of Bolivia, but the data suffer from numerous methodological problems and the hypothesized relationship has been abandoned. Stark (1972) added Yunga to the proposed Maya-Chipaya, but her evidence was even weaker than that for Maya-Chipaya. (See Campbell 1997, 324).

Tarascan-Quechua. As mentined above, Swadesh's (1967, 92-93) evidence for his proposed Tarascan-Quechua genetic relationship is extremely weak and it has never been accepted by linguists working with these languages. Swadesh's (1966) proposed Tarascan-Mayan relationship has similarly been rejected (details above).

Amerind. Joseph Greenberg's (1987) Amerind hypothesis — which proposed that all Native American languages, except the "Na-Dene" and Eskimo-Aleut groupings, belong to a single macrofamily - also makes claims about language families in Mesoamerica. This proposal has been rejected by almost all specialists in Native American languages. They find that valid methods do not permit reduction of Native American languages to fewer than about 180 independent language families (including isolates). Amerind has been heavily criticized. There are many errors in Greenberg's data. Where Greenberg stops —after assembling superficial similarities and declaring them due to common ancestry - is where other linguists begin. Similarities can be due to chance, borrowing, onomatopoeia, sound symbolism, nursery words [the mama, papa, nana, dada, caca sort], misanalysis, etc. Greenberg, however, made no attempt to eliminate these other explanations, and the similarities he amassed appear to be due mostly to accident and a combination of these other factors. (See Campbell and Poser 2008 for details.) In short, it is with good reason that Amerind has been rejected.

\subsection{Uncertain proposals}

Some of the proposals of distant genetic relationship are doubtful, but nevertheless still have some adherents among reasonable scholars. These proposals do not appear promising, but still deserve further study.

The Hokan hypothesis. The Hokan hypothesis originally proposed a relationship between several languages and language families of California, but soon many languages were added to "Hokan," including Tequistlatecan and Tlapanec-Subtiaba in Mesoamerica and Seri in northern Mexico (see, for example, Sapir 1920, 1925). Today there is no doubt that Tlapanec-Subtiaba belongs to the Otomanguean family (see above). For assessment of Hokan and various of the associated proposals, see Campbell 1997, 290-305. Most specialists in putative "Hokan" languages doubt the valitity of the Hokan hypothesis.

Otomanguean-Huave. Though some have favored the idea that Huave is possibly related to Otomanguean (as mentioned above), the evidence is not sufficient to support the claim (see Campbell 1997, 324).

Subdivissions of Amerind. As is well known, Joseph H. Greenberg's (1987) Amerind hypothesis of a genetic affinity among almost all languages of the Americas (except Eskimo-Aleut and "NaDene") has been rejected by almost all historical linguists and specialists in languages of the Americas. However, Greenberg's Amerind encompasses within it a number of proposed subordinate groupings, and it is conceivable that some of these could merit more consideration, despite Amerind itself being rejected. The subdivisions of Greenberg's Amerind that involve languages in Mesoamerica are the following -these groups have other putative members not found in Mesoamerica, not listed here except for a couple given in parentheses: 


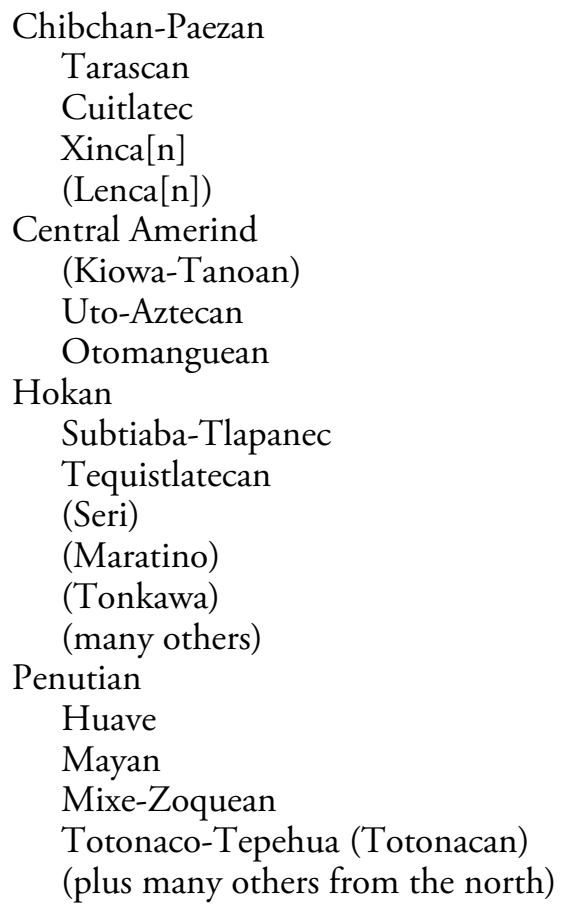

No one today supports a Central Amerind nor a Chibchan-Paezan grouping with these members; Hokan has extremely few supporters, and not even the few supporters of Penutian support it having any of these Mesoamerican languages in its membership.

\subsection{A recent proposal as an example}

The recent proposal of a distant genetic relationship is that of Brown et al. (2014), proposing to group Chitimacha, a language isolate of Louisiana, with the proposed but unfounded "Totozoquean" hypothesis (see Brown et al. 2011), which would group Totonacan and Mixe-Zoquean together.

There is not space here to present a detailed assessment of the data presented in favor of this hypothesis, but it is possible to give an overview of the kinds of problems involved which make this hypothesis non-viable. Nearly all of the 91 sets of lexical comparisons they present as possible cognates suffer from serious methodological shortcomings involving standard criteria (see Campbell and Poser 2008 for details about these criteria), summarized in what follows.

1. 26 sets involve compared forms that are not equivalent semantically, as in their example 7 , which compares forms in Chitimacha meaning 'shoot, stem' with Mixe-Zoquen 'cornfield' (no matching in Totonacan).

2. 21 sets compare short forms, composed of a single consonant and vowel. These could be true cognates, but they are so short that their similarity with forms in other languages could also easily be due just to chance. Their example 43 illustrates this problem: Chitimacha $p e(h)$ : 'auxiliary verb of horizontal position': Totonacan * $p a$ 'to be lying (second person)' (no Proto-Mixe-Zoquean matching).

3. Ten sets involve comparisons that are onomatopoeic and expressive/symbolic, for example, their 82. 'to cry, yell', and 88. 'musical horn' / 'blowgun', etc. (No Totonacan matching). 
4. 15 sets involve loans or possible loans. Several of the examples involve words that others have identified in the literature as loans; others have the cultural content of words that often are borrowed. For example, their example 6 'pumpkin' is widely borrowed from MixeZoquean into other languages (see Campbell and Kaufman 1976; see below for additional problems with this example.)

5. 59 sets involve proposed Chitimacha cognates with only one of the other two families involved, either only with Mixe-Zoquean or only with Totonacan, but not in both.

6. Three sets involve irregular sound correspondences. For example, their 68. gives ProtoMixe-Zoquean *tam 'fruit', but by their rules of sound correspondences *tan is expected.

7. 22 sets involved words with unexplained sounds (that compare only some of the sounds of the words compared, but not the whole word), or involve sounds that are missing or do not correspond to the sounds of the compared languages. As seen above, their set 6 . illustrates this problem, where only the boldfaced parts are compared: Chitimacha čiska 'squash' ('pumpkin') / Proto-Mixe-Zoquean *tsi?wa 'pumpkin' (squash). It involves only the comparison of a CV syllable, with no account for the rest of the sounds in the words in these languages (the ska of Chitimacha and the ?wa of Proto-Mixe-Zoquean). It also lacks a proposed cognate in Totonacan.

8. Twelve of the alleged sound correspondences lack sufficient examples among the proposed cognates to demonstrate that they recur with regularity, that the sounds actually do correspond. Of the 26 sound correspondences involving vowels given in the paper, one correspondence rests on but a single proposed cognate set (example 27) - to be considered a regular correspondence, it must be found repeated in other proposed cognates. Eight cases of proposed correspondences rest on only two putative cognate sets each.

In short, nearly all the data presented in support of this hypothesis are challenged for not measuring up when it comes to application of standard methods. The hypothesis as it stands cannot be accepted. Most of the other proposals of distant genetic relationship suffer from similar methodological problems involving the forms presented as evidence, though several of the proposals are far weaker even than this one.

\section{Conclusions}

Mesoamerican linguists can be justifiably proud of the successes in the comparative linguistic study of the languages of this area. There is much that remains to be done, many opportunities for continued work, and there is still very ample room for the application of the traditional techniques, especially the comparative method, where we can expect continued discoveries and refinements.

\section{REFERENCES}

Arana Osnaya, E., 1953, "Reconstrucción del proto-totonaco», in I. Bernal and D. Dávalos Hurtado (eds.), Huastecos, Totonacos y sus vecinos, Revista Mexicana de Estudios Antropológicos 13, 123-130.

—, 1958, "Afinidades lingüísticas del cuitlateco», International Congress of Americanists 33, 560-572.

Bellwood, P., 1997, «The prehistoric cultural explanations for the existence of widespread language families», in P. McConvell and N. Evans (eds.), Archaeology and linguistics: aboriginal Australia in global perspective, Melbourne: Oxford University Press, 123-134. 
Brinton, D. G., 1891, The American race, New York: D.C. Hodges.

Brown, C. H., D. Beck, G. Kondrak, J. K. Watters, and S. Wichmann, 2011, «Totozoquean», International Journal of American Linguistics 77, 323-372.

Brown, C. H., S. Wichmann, and D. Beck, 2014, "Chitimacha: a Mesoamerican Language in the Lower Mississippi Valley», International Journal of American Linguistics 80, 425-474.

Brown, C. H., and S. R. Wiткоwsкi, 1979, «Aspects of the phonological history of Mayan-Zoquean», International Journal of American Linguistics 45, 34-47.

CAmpbell, L., 1972, "Mayan loan words in Xinca», International Journal of American Linguistics 38, 187190.

—, 1977, "Quichean prehistory: linguistic contributions», in N. C. England (ed.), Papers in Mayan linguistics, Columbia, MO: University of Missouri Studies in Mayan linguistics, 25-54.

—, 1979, "Middle American languages», in L. Campbell and M. Mithun (eds.), The Languages of Native America: an Historical and Comparative Assessment, Austin: University of Texas Press, 902-1000.

—, 1988, The Linguistics of Southeast Chiapas, Papers of the New World Archaeological Foundation 51, Utah: Provo.

—, 1997, American Indian languages: the historical linguistics of Native America. Oxford: Oxford University Press.

—, 2011, «La investigación histórica de las lenguas aisladas, o ¿es raro el vasco?», in J. A. Lakarra, J. Gorrochategui, and B. Urgell (eds.), II Congreso de la Cátedra Luis Michelena, Vitoria Gasteiz: Editorial de la Universidad del País Vasco, 23-40.

—, 2013, Historical Linguistics: an Introduction (3 ${ }^{\text {rd }}$ edition), Edinburgh: Edinburgh University Press, and Cambridge, MA: MIT Press.

—, in press, «History and reconstruction of the Mayan languages», in J. Aissen, N. C. England, and R. Zavala Maldonado (eds.), The Mayan Languages, London: Routledge.

Campbell, L., and T. Kaufman, 1976, «A linguistic look at the Olmecs», American Antiquity 41, 80-89.

—, 1985, «Mayan Linguistics: where are we now?», Annual Review of Anthropology 14, 187-98.

Campbell, L., T. Kaufman, and Th. Smith-Stark, 1986, «Mesoamerica as a linguistic area», Language 62, 530-570.

Campbell, L., and R. Langacker, 1978, «Proto-Aztecan vowels: parts I, II, \& III», International Journal of American Linguistics 44.2, 85-102; 44.3, 197-210; 44.4, 262-279.

Campbell, L. and D. Oltrogge, 1980, «Proto-Tol (Jicaque)», International Journal of American Linguistics 46, 205-223.

Campbell, L. and W. J. Poser, 2008, Language classification: history and method, Cambridge: Cambridge University Press.

Charencey, Ch. F. H., Le Comte de, 1870, Notice sur quelques familles de langues du Mexique. Havre: Imprimerie Lepellatier.

—, 1872, Recherches sur les lois phonétiques dans les idiomes de la famille mame-huastèque, Paris: Maisonneuve.

—, 1883, Mélanges de philologie et de paléographie américaines, Paris: Ernest Leroux.

Delbrück, B., 1888, Altindische Syntax (Syntaktische Forschungen, no. 5.) Halle an der Saale: Niemeyer.

—, 1893-1900, Vergleichende Syntax der Indogermanischen Sprachen (Teil 3, K. Brugmann and B. Delbrück, 1900, Grundriss der vergleichenden Grammatik der indogermanischen Sprachen), Strassburg: K.J. Trübner.

England, N. C., 1991, "Changes in basic word order in Mayan languages», International Journal of American Linguistics 57, 446-486.

Friedrich, P., 1971, «Dialectal variation in Tarascan phonology», International Journal of American Linguistics 37, 164-187.

Greenberg, J. H., 1987, Language in the Americas. Stanford: Stanford University Press.

Halpern, A. M., 1942, "A theory of Maya tš-sounds», Notes in Middle American Archaeology and Ethnology, Carnegie Institute of Washington, 1, 51-62. 
Harvey, H. R., 1972, «The Relaciones Geográficas, 1579-1586: Native languages», in R. Waucope (general editor), Handbook of Middle American Indians, vol. 12: Ethnohistorical sources, ed. by H. Cline, Austin: University of Texas Press, 279-323.

Heaton, R., in press, "Language Isolates of Mesoamerica and Northern Mexico", in L. Campbell, Th. Dougherty, and A. Smith (eds.), Language isolates, London: Routledge.

Hervás y Panduro, L., 1800-1805, Catálogo de las lenguas de las naciones conocidas y numeracion, division, $y$ clases de estas segun la diversidad de sus idiomas y dialectos, volumen I (1800): Lenguas y naciones Americanas. Madrid: Administración del Real Arbitrio de Beneficencia.

Hendrichs Pérez, P. R., 1947, "Breve informe del idioma cuitlateco», International Congress of Americanists 27, 289-295.

Hill, J. H., 2001, «Proto-Uto-Aztecan: a community of cultivators in central Mexico?», American Anthropologist 103, 913-914.

-, 2002, "Proto-Uto-Aztecan cultivation and the northern devolution», in P. Bellwood and C. Renfrew (eds.), Examining the farming/language dispersal hypothesis, Cambridge: McDonald Institute for Archaeological Research, 331-340.

Justeson, J. S. and T. Kaufman, 1993, "A Decipherment of Epi-Olmec Hieroglyphic Writing», Science 259, 1703-1711.

Kaufman, T., 1964, «Materiales lingüísticos para el estudio de las relaciones internas y externas de la familia de idiomas Mayanos», in E. Vogt (ed.), Desarrollo Cultural de los Mayas, México: Universidad Nacional Autónoma de México, 81-136.

—, 1969, «Teco- a new Mayan language», International Journal of American Linguistics 35, 154-174.

—, 2002, Reconstructing Mayan morphology and syntax, Unpublished ms. University of Pittsburgh.

—, 2006, "Oto-Mangean Languages», in K. Brown (ed.), Encyclopedia of Language and Linguistics (2nd edition), Oxford: Elsevier, volume 9, 118-124.

Kaufman, T., with J. Justeson, 2003, A Preliminary Mayan Etymological Dictionary. <www.famsi.org/ reports/01051/pmed.pdf>.

Kaufman, T., and J. Justeson, 2008, «The Epi-Olmec Language and its neighbors», in Ph. J. Arnold III and Ch. A. Pool (eds.), Classic Period Cultural Currents in Southern and Central Veracruz, Washington, D.C.: Dunbarton Oaks Researcy Library and Collection, 55-83.

Kaufman, T., and W. Norman, 1984, "An outline of Proto-Cholan phonology, morphology, and vocabulary», in J. S. Justeson and L. Campbell (ed.), Phoneticism in Maya Hieroglyphic Writing (Institute for Mesoamerican Studies, Publication 9). Albany: State University of New York, 77-166.

Law, D., 2014, Language contact, inherited similarity and social difference: the story of linguistic interaction in the Maya lowlands, Amsterdam: John Benjamins.

Lehmann, W., 1920, Zentral-Amerika, Berlin: Museum für Völkerkunde zu Berlin.

Lemley, H. V., 1949, «Three Tlapaneco stories from Tlacoapa, Guerrero», Tlalocan 3, 76-82.

LongaCre, R. E., 1968, «Comparative Reconstruction of Indigenous languages», in Th. Sebeok (ed.), Current Trends in Linguistics, The Hague: Mouton, vol. 4, 320-360.

MacKay, C. J. and F. R. Trechsel, 2014, «Diagnósticos morfológicos para la clasificación de las lenguas totonaco-tepehuas. Lenguas, estructuras y hablantes», in R. Barriga Villanueva and E. Herrera Zendejas, Estudios en Homenaje a Thomas C. Smith Stark, México D.F.: Colegio de México, Centro de Estudios Lingüísticos y Literarios, 843-870.

McQuown, N. A., 1942, "Una posible síntesis lingüística macro-mayance», Mayas y Olmecas, Tuxtla Gutiérrez: Sociedad Mexicana de Antropología, Reunión de Mesa Redonda sobre problemas antropológicos de México y Centro América, 37-38.

—, 1955, «The indigenous languages of Latin America», American Anthropologist 57, 501-569.

—, 1956, «The classification of the Mayan languages», International Journal of American Linguistics 22, 191195.

Mora-Marín, D. F., 2003, "Historical reconstruction of Mayan applicative and antidative constructions», International Journal of American Linguistics 69, 186-228. 
—, 2016, "Testing the Mayan-Mijesokean hypothesis», International Journal of American Linguistics, 82, 125-180.

Norman, W., 1978, «Advancement rules and syntactic change: the loss of instrumental voice in Mayan», Berkeley Linguistics Society 4, 458-476.

Norman, W. M. and L. CAmpbell, 1978, «Toward a Proto-Mayan syntax: a comparative perspective on grammar», N. C. England (ed.), Papers in Mayan linguistics (Studies in Mayan Linguistics, 2, Miscellaneous Publications in Anthropology, 6), Columbia, Missouri: Museum of Anthropology, University of Missouri, 136-156.

Olson, R. D., 1964, «Mayan affinities with Chipaya of Bolivia I: Correspondences», International Journal of American Linguistics 30, 313-324.

—, 1965, «Mayan affinities with Chipaya of Bolivia II: Cognates», International Journal of American Linguistics 31, 29-38.

Powell, J. W., 1891, Indian linguistic families of America north of Mexico. Seventh annual report, Bureau of American Ethnology, 1-142. Washington, D.C.: Government Printing Office [Reprinted 1966, in F. Boas, Introduction to Handbook of American Indian languages; J. W. Powell, Indian linguistic families of America north of Mexico, ed. by Preston Holder. Lincoln: University of Nebraska Press].

Renfrew, C., 1994, "World linguistic diversity», Scientific American 270, 116-123.

—, 2000, «At the edge of knowability: towards a prehistory of languages», Cambridge Archaeological Journal 10.1, 7-34.

Rensch, C. R., 1976, Comparative Otomanguean phonology (Language Science Monograph 14), Bloomington: Indiana University Press.

—, 1977, "Classification of the Otomanguean languages and the position of Tlapanec», Two studies in Middle American comparative linguistics, 53-108 (SIL Publications in Linguistics, 55), Arlington: SIL and University of Texas at Arlington Press.

Robertson, J. S., 1992, The history of tenselaspect/mood/voice in the Mayan verbal complex, Austin: University of Texas Press.

Rogers, Ch., 2016, The use and development of the Xinkan languages, Austin: University of Texas Press.

SAPIR, E., 1913-1919, «Southern Paiute and Nahuatl, a study in Uto-Aztecan», Journal de la Société des Américanistes 10, 379-425; 11, 443-488 (Also 1915, American Anthopologist 17, 98-120, 306-328).

—, 1920, "The Hokan and Coahuiltecan languages», International Journal of American Linguistics 1, 28090.

—, 1925, «The Hokan affinity of Subtiaba in Nicaragua», American Anthropologist 27, 402-35, 491-527.

—, 1929, "Central and North American languages», Encyclopaedia Britannica, 14th edition, 5, 138-41 [Reprinted 1949, Selected Writings of Edward Sapir, ed. by David G. Mandelbaum, 169-78. Berkeley and Los Angeles: University of California Press. Also reprinted 1990, Collected Writings of Edward Sapir, Vol. 5: American Indian languages, first part, ed. by William Bright, 95-104. Berlin: Mouton de Gruyter].

SAUER, C., 1934, The distribution of aboriginal tribes and languages in northwest Mexico (Ibero-Americana, 5), Berkeley and Los Angeles: University of California Press.

Seler, E., 1887, Das Konjugationssystem der Mayasprachen, Berlin: Unger [Reprinted 1902, in E. Seler, Gesammelte Abhandlungen zur Amerikanischen Sprach- und Altertumskunde 1, 65-126. Berlin: Ascher. Reissued, 1960, Graz: Akademische Druck- und Verlagsanstalt].

STARK, L. R., 1972, «Maya-Yunga-Chipayan: a new linguistic alignment», International Journal of American Linguistics 38, 119-135.

STOLL, O., 1885, «Supplementary remarks to the grammar of the Cakchiquel language», in D. G. Brinton (ed.), Proceedings of the American Philosophical Society 22, 255-268.

—, 1912-1913, "Zur Psychologie der indianischen Hochlandsprachen von Guatemala», Festschrift der Geographisch-ethnographischen Gesellschaft in Zürich, 34-96.

StubBs, B. D., 2011, Uto-Aztecan: a comparative vocabulary, Blanding: Rocky Mountain Books and Productions. 
SuÁrez, J., 1975, Estudios Huaves (Colección Científica Lingüística, 22), México: Instituto Nacional de Antropología e Historia, Departamento de Lingüística.

-, 1986, "Elementos gramaticales otomangues en tlapaneco", in B. Elson, Language in global perspective: papers in honor of the 50th anniversary of the SIL, 1935-1985, Dallas: SIL, 267-284.

Swadesh, M., 1966, "Porhé y Maya», Anales de Antropología 3, México: Universidad Nacional Autónoma de México, 173-204.

—, 1967, «Lexicostatistic classification», in R. Wauchope, Handbook of Middle American Indians, Vol. 5: Linguistics, ed. by N. A. McQuown, Austin: University of Texas Press, 79-115.

Turner, P. R., 1969, «Proto-Chontal phonemes», International Journal of American Linguistics 35, 34-37.

Waterhouse, V., 1969, «Oaxaca Chontal in reference to Proto-Chontal», International Journal of American Linguistics 35, 231-233.

Weitlaner, R. J., 1939, «Notes on the Cuitlatec language», El México Antiguo 4, 363-373.

Wichmann, S., 1995, The Relationship Among the Mixe-Zoquean Languages of Mexico. Salt Lake City: University of Utah Press. 